\title{
İsmayıl Hakkı Baltacıoğlu'nun İletişim Araştırmalarına Katkıları
}

- Zeynep Gültekin Akçay

Dr. Öğr. Üyesi Sivas Cumhuriyet Üniversitesi zga@cumhuriyet.edu.tr ORCID ID: 0000-0003-30503090

\begin{abstract}
ÖZET
Bu çalışma, erken Cumhuriyet dönemi entelektüellerinden Ismayıl Hakk Baltacıoğlu'nun Türkiye'de iletişimin henüz müstakil bir araştırma alanı olarak tanımlanmadığ dönemde yaptığı çalışmalarıyla, iletişim araştırmalarına sunduğu katklyı konu edinmektedir. Cumhuriyet'in ilk dönemlerinde toplumbilim alanında çalışmalar yapan pek çok erken dönem entellektüel gibi İsmayll Hakkı Baltacıoğlu da kendi uzmanlık alaninda düsüncelerini ortaya koyarken iletișim bilimine ve iletişim araçlarına dair yol açıcı fikirler sunmuştur. Baltacıoğlu, yeni toplumun yaratılmasinda ananeci ve kültürcü modernleşme üzerinde durmuştur. Kültürcü modernleşmenin özünü medeniyet ve kültür ikiliğiyle açıklamıştır. Toplumun medenileşmesinde kitle iletişim araçlarının kurucu rol oynadiğından bahsetmiştir. Kültür üzerine detaylı çalışmalar yapmış, kültürü̈n hızla üretilip tüketilerek yozlaşmasını 'değer anarşisi' kavramılla tanımlamıștır. 'Değer anarşisi'nin oluşma nedenleri arasına gazete, dergi gibi iletişim araçlarını da dâhil etmiştir. Gazetenin, haber yanında fikirleri de aktarması nedeniyle tarafsız olamayacağından bahsetmiştir. Kültürcü fikirleri içinde dil meselesine önem vermiş, bu noktada gazetelerin okunma oranlarının arttırlabilmesi için, kullandıkları dilin öz Türkçe olması gerektiğini vurgulamıștır. Eğitimci perspektifinden bakarak, gazetelerin saygınlığını sürdürebilmeleri için çalışanlarının eğitimli olması gerektiğine değinmişstir. Türk basın tarihini 'ögretici, hava atma ve eksperler' olarak üç döneme ayırmıştır. Ananeci toplum anlayışından yola çıkarak, folklorun korunması ve geliştirilmesinde yerel basını önemli bir unsur olarak görmüş ve bu gazeteleri 'il gazeteleri' olarak tanımlamıştır. Dergiyi, konulara derinlemesine yoğunlaşmadığ için kitaptan ve günceli kovalamadiğı için de gazeteden ayırmıştır. Yukarıda bahsedilen düşüncelerden yola çıkarak, araștırmada, semptomal okumayla İsmayll Hakk Baltacıoğlu'nun iletişim bilimlerine katkıları, ortaya koyulmaya çalışılmıştır. Çalışma, Baltacıŏ̆lu'nun gazete ve dergiye dair fikirlerini kapsamaktadır.
\end{abstract}

Anahtar Sözcükler: İsmayıl Hakk1 Baltacıŏlu, Değer Anarșisi, Gazetecilik, İl Gazeteleri, Tematik Dergicilik.

Geliş Tarihi $\quad 28.07 .2020$

Kabul Tarihi

26.11.2020

Yayın Tarihi

15.01 .2021 


\section{Contribution of Ismayil Hakkı Baltacıoğlu to Communication Studies}

- Zeynep Gültekin Akçay

Asst. Prof. Sivas Cumhuriyet University

zga@cumhuriyet.edu.tr ORCID ID: 0000-0003-30503090

\begin{abstract}
This study addresses the contribution of Ismayll Hakk Baltacioglu. Like many intellectuals Baltacioglu presented leading opinions with regard to communication science and communication means while he expressed his thoughts in his own specialization field. He mentioned that mass media played a founding role in the civilization of society. He conducted detailed studies on culture and defined the degeneration of culture through its fast production and consumption with the concept of 'value anarchy'. He also counted the communication tools such as newspapers and magazines among the reasons for the formation of 'value anarchy' in the society, and made studies on these tools. He mentioned that the newspaper could not be neutral because it conveys ideas as well as news. He emphasized the language issue among his culturalist ideas and emphasized that the language they use should be in Turkish in order to increase the reading rates of the newspapers. He mentioned that newspaper staff should be well educated in order for newspapers to maintain their reputations. He divided Turkish press history into three periods as 'instructive, flaunting and experts'. He considered local press as a substantial factor in preservation and improvement of folklore and defined those newspapers as 'provincial newspapers'. He distinguished magazines from books. This study tried to reveal the contributions of İsmayll Hakk Baltacioğlu to the communication sciences via symptomatic reading. The study includes Baltacioğlu's ideas about newspapers and magazines.
\end{abstract}

Keywords: İsmayıl Hakkı Baltacıŏlu, 'Value Anarchy', Journalism, 'Provincial Newspapers', Thematic Periodical. 


\section{GİRIŞ}

Anlam üretimi, paylaşımı, güç mücadelesi, ileti alışverişi gibi çeşitli açılardan tanımlanan ve insani faaliyetin en temel öğelerinden biri olan iletişim olgusu, birçok disiplinin (felsefe, tarih, dilbilim, toplumbilim, psikoloji, biyoloji, siyaset bilimi vb.) kavşağında yer almıştır. Toplumsal olgu ve olayların anlaşılmaya çalışıldığı dönemlerde, iletişim bu disiplinlerin içinde ele alınmış ancak uzun zaman bir bilim alanı olarak değerlendirilmemiştir ${ }^{1}$. Tarihin en şiddetli ve öldürücü olaylarının yaşandığı yirminci yüzyılda, iletişim, hem ideolojik hem de teknik bir gereksinim olarak, ele alınması gereken bir olgu haline gelmiştir. Gazeteler, politik kampanyalara ilişkin basılı yayınlar, radyo, televizyon, sinema gibi dönemin teknik yenilikleri olan kitle iletişim araçlarının; kamuoyunun incelenmesi, örgütsel ağlar, kitle kültürü, medyanın etkileri gibi meseleler açısından ayrıca sorgulanması gerektiği düşülmüştür. Bunun yanında, iki dünya savaşında dünyanın politik haritasının alt üst olması, ideolojik yapılanma da iletişim üzerine özel olarak soruların oluşturulmasını kaçınılmaz kılmıştır (Bourse \& Yücel, 2012, s. 17). Bu noktadan sonra, iletişim üzerine bağımsız araştırmalar başlamış²; kitle iletişiminin etkileri, insanların kitle iletişim araçlarını kullanımları, kitle iletişim araçlarından öğrenme süreçleri, kitle iletişim araçlarının insanların değer ve görüşlerini şekillendirmedeki rolü, kitle iletişiminin mülkiyeti ve kontrolü gibi konular öncülünde ilerlemiştir.

İletişimin, Türkiye'de ele alınması Batı'yla ortaklık göstermiştir. Sosyoloji, tarih, ekonomi, antropoloji gibi alanlarda araştırma yapan erken Cumhuriyet dönemi bilim insanları, toplumu açıklama ve anlama çabası içinde iletişımin farklı noktalarına değinmişlerdir. İletişim alanının yek pare ele alınması ise Oya Tokgöz (2003), Korkmaz Alemdar ve İrfan Erdoğan ${ }^{3}$

\footnotetext{
${ }^{1}$ Bu noktada James Carey, iletişim çalışmaları alanının sınırlarını çizmenin zorluğundan şu şekilde bahsetmektedir: “17. Yüzyıldan günümüze matbaa, broşür, reklamlar, ucuz romanlar, sansür, İngiliz Ceza Mahkemesi, kent kamusu, düşünce ve basın özgürlüğü ile ilgili pek çok başlık ve konu üzerine yazan âlimler, bilim insanları avukatlar, din adamları, eli kalem tutan kişiler, gazeteciler, siyasetçiler ve serbest entellektüeller vardır" (Özçetin, 2018, s. 54). "Lazarsfeld, Goffman, Hall, Adorno, Marcuse, Watzlawick gibi iletişimle ilgilenen ve iletişim alanında ünlü birçok isim de, böyle bir bilim alanı kurmayı hiçbir zaman gerçekten amaçlamamışlardır. Hiçbir zaman iletişim adlı bir bilim ya da disiplin kurmamışlardır" (Bourse \& Yücel, 2012, s. 16).

${ }^{2}$ Burak Özçetin (2018, s. 51-55), on dokuzuncu yüzyılın başında telgraf, gazete gibi iletişim araçlarına dair çalışmalardan bahsetmekle birlikte iletişim alanında müstakil çalışmaların yirminci yüzyılın başlarına rast geldiğini belirtmektedir.

${ }^{3}$ Türkiye'nin önemli yapısal sorunları genel olarak sosyal bilimlerin gelișimini etkilemiş bu nedenle de katkılar sınırlı olmuştur. Böyle bir ortamda geleneksel sosyal bilim dalları iletişim alanına özel bir ilgi de göstermemişleridir. Tarihçiler basın tarihini yazmadıkları gibi, sosyologlar da iletişimin özel alanlar arasında yer alabileceğini düşünmemişlerdir (Alemdar \& Erdoğan, 1998, s. 3).
} 
(1998), Serdar Öztürk (2008) gibi isimlerin de belirttiği üzere Batı'ya göre çok daha sonra gerçekleşebilmiştir. Bununla birlikte, bu erken dönem sosyal bilim düşünürlerinin iletişime dair düşüncelerinin ne olduğunu, nasıl tartıştıklarını ortaya koyan araştırmaların yakın zamanda arttığının da altını çizmek gerekir. Çiler Keleş’in (1999) sosyoloji çalışmaları ve toplumsal yapı kavrayışından yola çıkarak Behice Boran'ın iletişim alanına, ekonomi politik bir açıdan yaklaştığına değinen makalesi öncü çalışmalardan bir tanesidir. Halkbilimci Pertev Nail Boratav'ın incelendiği makalede ise, iletişimin antropolojik yönüyle değerlendirilebileceği ortaya koyulmaktadır (Öztürk, 2006a). Sabri Ülgener'in, ulaşım yolları ile tekke, tarikat ve esnaf örgütleri ile ilgili ortaya koyduğu düşüncelerin iletişim ile doğrudan ilişkisi de bir bir başka çalışmada tartışı1mıştır (Öztürk, 2006b). Doğan Avcıoğlu'nun Türkiye'nin geri kalmışlık sorununun nedenlerine ve çözümlerine dair açıklamaları arasında iletişime dair nelerin bulunduğu sorusu üzerinde de durulmuştur (Öztürk, 2006c). Niyazi Berkes’in kitle iletişim araçlarına yönelik verileriyle Türk basın tarihine hangi açılardan katkı sağladığı ise başka çalışmanın konusu olmuştur (Gürses, 2008). Mübeccel Kıray’ın Ereğli Ağır Sanayiden Önce Bir Sahil Kasabası ve Örgütleşemeyen Kent: İzmir isimli makalelerinden yola çıkarak Kıray’ın iletişim araçları ve alanına ilişkin görüşleri de incelenmiştir (Bulut, 2012). Tarihçi Fuat Köprülü’nün eserleri ise, iletişim alanıyla yakın ilişkili olan popüler kültür üzerinden tartışılmış ve bu sayede popüler kültürün Türkiye'deki kökenlerini, değişimlerini ve özelliklerinin anlaşılabileceği belirtilmiştir (Öztürk, 2008). Siyaset Bilimci Nermin Abadan Unat'ın Siyasal seçimlere ilişkin yaptığı araştırmalarda kitle iletişim araçlarının etkilerine değinmesi, siyasal iletişim alanına sunduğu katkılar olarak ortaya koyulmuştur (Öztürk, 2008). Yakın zamanda ise Mahmut Akgül'ün (2020), toplumbilimci Mümtaz Turhan'1 incelediği makalesinde, Turhan'ın 1930’larda laboratuvar ortamında yaptığı deneysel çalışmalarla iletişimin sözsüz boyutuna katkı sağladığını belirtilmiş, ayrıca Turhan'ın kitle psikolojisi üzerinden kültürlerarası iletişimi açıkladığına değinilmiştir.

Yukarıda değinilen, tarih, toplum bilim, halkbilimi, siyaset bilimi alanlarındaki bu çalışmaların her biri Türkiye'de önde gelen isimlerin iletişim bilimi ile ilişkisi üzerinedir. Fark edildiği üzere henüz birkaç bilim alanındaki çalışmaların iletişim ile ilişkisi gün yüzüne çıkarılmıştır. Hâlbuki sanat, eğitim, mühendislik gibi pek çok alanda gün yüzüne çıkarılmayı bekleyen pek çok isim vardır. Bu isimlerden biri de, 1923 yılında Darulfünun ve Cumhuriyet'in 
ilk rektörü, 'Eğitim Reformu $\mathrm{Ak}{ }^{4}{ }^{4}$ ' nın temsilcilerinden eğitim bilimci İsmayıl Hakk1 Baltacıoğludur5 . Baltacıŏlu, eğitim, sosyoloji, tiyatro, vekillik dönemi faaliyetleri gibi pek çok konuda araştırma konusu olmuş; reformcu eğitim (Altın, 2014; Kadığ̆lu Ateş \& Akyol, 2016), Kemalist modernleşme projesi (Akkanat, 2017), kadın imgesi (Özman, 2006), köy enstitüleri (Aytaç, 2017), ekoloji ve Avrupa Birliği (Vergili, 2014; Özüçetin \& Mutlu , 2016), öz tiyatro kuramı (Tekerek, 2005; Pekman, 2003) ve Bergsoncu ve Durkheimc1 toplum değerlendirmesi (Kaçmazoğlu, 1999) gibi alt başlıklarda incelenmiştir.

Düşüncelerinde toplumun geçirdiği çeşitli süreç ve dönüşümlerin izi görülen Baltacıoğlu, Cumhuriyet'in ilk yıllarında 'yeni bir toplum' yaratma fikrine destek vermiştir. Yeni rejimin rotasının ananeci ve kültürcü modernleşme olması gerektiğini belirtmiştir (Baltacioğlu, 1950a, s. 43-57). Peyami Safa, Ahmet Ağaoğlu, Hilmi Ziya Ülken, Mustafa Şekip Tunç gibi muhafazakâr modernlik anlayışın kavramsal çerçevesini kuran aydınlardan olan Baltacıoğlu'nun çalışmalarında, ananecilik, "millet olmanın temel koşulu olarak tanımlanır. Ananeleri ya da bütün zamanlarda canlı ve kuvvetli kalan örfleri tanımak anlamında kullanılan kavram, aynı zamanda düşünürün muhafazakârlık sınırını da belirlemiştir. Bu bağlamda, ananeleri, değişim içerisinde sürekliliği sağlayacak formülasyonlar ya da muhafazakâr bir değişim anlayışının unsurları olarak okumak mümkündür. Evrimci görüş çerçevesinde, bir oluş fikri olarak ele alınan millet, ancak geçmiş, bugün ve gelecek arasındaki bağlantının kurulmasıyla varlık ve devamlılık kazanacaktır. Geçmişten kopmayarak geleceğe sarkmak, arkasını tarihe dayayarak ileriye atılmak düsturlarından hareketle, geçmiş ananeler aracılığıyla bugün içerisinde yaşatılarak, yaratıcı bir sentezle geleceğe yanstılacaktır” (Özman, 2006, s. 193-194). Modernleşme ya da kendi deyimiyle Avrupalılaşmak, temelde medeniyet ile kültür arasındaki farkın göz ardı edilmesi nedeniyle çıkmaza girmektedir. Kültür, milletin içinde doğar, ona özgüdür ve değişmez. Kültürün olabilmesi için geleneğin olması gereklidir.

\footnotetext{
${ }^{4}$ 1900-1945 arasında her ülkede ortaya çıkan reformcu hareketler, kendi içerisinde çeşitli akımların gelişmesine öncülük etmiştir. Çeşitli reform modelleri geliştirilmiş ve uygulama girişimleri başlamıştır. Bütün bu girişimler eğitim reformu çalışmalarının fikri temellerini hazırlamıştır. Bu hareketin temel aldığı konular; geleneksel eğitimi köklü değişimden geçirmek, çağa uygun yeni eğitim modelleri yaratmak; dolayısıyla 'Yeni Adamlar' yaratmak/yetiştirmektir (Güngör M. , 2008, s. 56).

${ }^{5} 1886$ 'da İstanbul'da doğan Baltacıoğlu, pedagog, oyun yazarı ve 'Eğitim Reformu Akımı' nın Türkiye'deki temsilcilerindendir. 1923 yllında Darulfünun'un ve Cumhuriyet'in ilk rektörü olmuştur. Darulfünun'un 1933 y1lında tasfiye edilmesinin ardından kurulan İstanbul Üniversitesi'nden tasfiye edilmiştir. 1934'te 'Yeni Adam' isimli haftalık dergiyi çıkarmaya başlamıştır. 1942 yılında Ankara Dil Tarih ve Coğrafya Fakültesi'ne profesör olarak atanmıştır. 1943 ve 1946 yıllarında iki kez Cumhuriyet Halk Partisi’nden VII. ve VII. dönem milletvekili seçilmiştir. Hat sanatında kendine özgü olan 'Alev yazısı' (Hatt-1 muavvec) ismi verilen üslubu oluşturmuştur (Altın, 2014, s. 222-223).
} 
Medeniyet ise, öğrenilebilir, uluslararasıdır ve teknik ile değişebilir (Baltacıoğlu, 1950a, s. 46). Medeniyetin öğrenilmesi ve buna bağlı olarak kalkınmanın gerçekleşmesinde eğitimi işaret ettiği kadar, kitle iletişim araçlarının önemine de vurgu yapan Baltacıŏ̆lu, radyo, gazete, dergi gibi kitle iletişim araçlarının ‘toplumun medenileşmesi’ndeki rolü üzerine fikirler önermiştir. Bu makalenin amacı, sosyoloji, eğitim, felsefe, tiyatro, sanat gibi alanları kapsayan geniş bir yelpazede çalışmaları bulunan İsmayıl Hakkı Baltacıoğlu'nun iletişim araştırmalarına yaptığı katkıları ortaya koymaktır. Baltacıoğlu'nun bahsedilen düşünceleri içinde tiyatro, sanat, radyo, sinema gibi konular da bulunmakla birlikte bu çalışmanın kapsamı dışında tutulmuştur. $\mathrm{Bu}$ noktada, çalışma, Baltacıŏlu'nun 'değer anarşisi', 'tarafsız gazete yoktur', 'gazetecilikte dil ve eğitim', 'il gazeteleri', 'dergicilikte uzmanlaşma' gibi kitle iletişim araçlarına dair öne sürdüğü düşünceleriyle sınırlandırılmıştır. Makalede Baltacıoğlu'nun eserleri semptomal okumayla incelenmiştir.

\section{METINLERİ SEMPTOMAL OKUMAK}

Farklı disiplinlerde üretilmiş metinlerin semptomal okuma ile iletişim bilimine katkı sağlayabileceğini öne süren Serdar Öztürk (2009, s. 277) bu analiz tekniği ile aynı eksendeki başka çalışmalara da bir zemin oluşturabileceğini ortaya koymaktadır. Semptomal okuma, Louis Althusser ve Etinne Balibar'in (2007, s. 43) Kapital'i Okumak isimli eserinde kullandıkları bir kavramdır. Marx'ın Kapitali'ne yeni bir 'okuma' öneren ve metafizik dogmaları yıkmaya çalışan Althusser, bu köklü eserin dikkatli okunması ile felsefesinin anlaşılabileceğini belirtmiş ve bu okuma tarzına 'semptomal okuma' ismini vermiştir. Eserin doğru okunması içinse, eser ait olduğu sorunsal içine yerleştirilerek, sorunsalı ifade eden teorik yapı aydınlatılmalıdır (Timur, 2005, s. 108-109). Semptomatik okuma, metinde açıkça sorulmamış sorulara verilen yanıtların paradoksunu tanımlamayı içerir ve satırların arası okunmadan teorik belirsizlik ortadan kaldırılamaz. Sunulan cevap için belirtilmemiş soruyu arayan bu okuma, yorumlamayı içermez ancak görünmez olanı tanımlayan bir bilgi üreterek metindeki boşlukları doldurur (Young, 2017, s. 40).

Mevcut sorunsalın görünür alanı içinde kendi görünmezinin bir yanının kaçamak varlığını üretmeye varır; bu durumda bu ürün ancak görünmez olabilir. Bu görünmez olanı görmek için gözden kaçanların görmek için, söylemin tamlığı içindeki bu boşlukları, metnin sıkışıklığı içinde 
bu beyaz bırakılmış yerleri tanımlamak için, keskin ya da dikkatli bir bakıştan başka bir şey gerekir (Althusser, 2007, s. 43)

Semptomal okuma, ampirist okumadan taban tabana zittır. Ampirist okuma, olgulara ve maddeye doğrudan duyularla algılandığı biçimde bilgi üretir. Ancak bu bilgiler doğrudan bilime götürmez çünkü ham bilgiler karmaşık yapı içindedirler (Timur, 2005, s. 111). Klasik ekonomi politiğin görmediği, görmediği değil, gördüğü şeydir diyen Althusser, klasik politik iktisatçıların bir şeyi bilmeden görmeyi tercih ettiklerini vurgulamaktadır (Young, 2017, s. 42). Semptomal okuma ile bir bilim insanı kendi çalıșma alanı dâhilinde bir metni ayıklama faaliyeti içerisinde olduğunda bilimsel olan ile bilimsel olmayan ayrılabilir. Tıpkı altın cevherinin doğada karışık halde bulunduğu toprak, kil ve kaya parçalarından temizleme operasyonunda olduğu gibidir. Bu anlamda 'semptomal okuma', 'önceden var olan şeyi' 'dönüş̧ürmek' anlamına gelen bir üretimdir (Öztürk, 2009, s. 277). Bu okuma, Jacques Ranciere'in, şiir için belirttiği 'yapım ya da yeniden yapımdır' fikri gibi her zaman ikili olmasındandır. Okuma tekten, ikiye geçtiğinde semptomatik hale gelir: Masumiyetten bir anda suçluluk görünür hale gelir (Young, 2017, s. 42). Metinde bulunan öğelere odaklanarak okuma yapıldığında gizli/örtük bir şeyin yüzey işaretlerini yakalamak mümkündür. Metni yazanları motive eden soruları ve bu soruları nasıl ifade ettiklerini ortaya koyan bu okuma metnin kendisinin doğrudan ifade edemediği noktaları ortaya çıkarır (Bewes, 2010, s. 5). Metinler, kendilerinin sormadıkları sorularla şekillendiği semptomlar içerir. Metinlerin dışında kalan soruların sorulmasına olanak sağlayan semptomal okuma tarihsel arayışlarda daha esnek olmak anlamına da gelmektedir. Örneğin edebi metinlerde yapılacak semptomal okuma ile insanlık tarihinin henüz anlaşılamamış olduğu anlaşılacaktır (Best \& Marcus, 2009, s. 3-5).

Farklı disiplinlerden, iletişim araştırmaları ile ilgili çalışmalar sempotamal okumayla değerlendirildiğinde bu alana katkı sunacaktır. Farklı disiplinlerde yazılmış metinlerin, iletişim açısından okunması, metinlerin iletişim disipliniyle ilgili görünmeyen yönlerinin ele alınmasına, bu konuda gözden kaçanları gün yüzüne çıkarmak noktasında önemlidir. Nitekim dünyadaki iletişim tarihi literatürü yazılırken, farklı disiplinlerdeki çalışmalarda iletişimi ilgilendiren veriler, kavramlar ve hatta kuramların izini görmek mümkündür. Bu makale, İsmayıl Hakkı Baltacığlu'nun eserlerini semptomal okuyarak, iletişim alanına katkılarını ortaya koymaya çalışmaktadır. 


\section{2. "TEKNİK, MEDENILEŞME YOLUNDA ÖNEMLİ BİR ARAÇTIR"}

Baltacıŏ̆lu'na göre, din ve kültür, toplumların oluşmasında ayrı bir yere sahiptir. Toplumsal kurum ve olayları şekillendiren bu kuvvetler bilinen en ilkel toplumlarda bile vardır. Yeryüzündeki toplumlar dinsiz ve kültürsüz olmadığı gibi bunlarsız ne bilim, ne ekonomi, ne teknik, hiçbir sosyal kurum olamaz (Kaçmazoğlu, 1999, s. 193). Kültür, Baltacıoğlu'na (Baltacığlu, 1939, s. 366) göre, medeniyet gibi akıl ve öğrenimi dışarıdan, yabancıdan alınmayan, milletin tarihi benliğinden çıkan şeydir. Toplumun gelişmesi ve ilerlemesi için çıkış yolu Batı'dan kültürün (din, dil, sanat, aile, hukuk, ahlak, zevk, mitoloji, masal, yemek vb.) değil, medeniyetin (ilim, fen, teknik) alınmasıdır. Bu noktada kültürün taşıyıcısı ilim, fen ve teknik yani medeniyet unsurlarıdır. Toplumların ilerleme sürecinin anlaşılması için mutlaka tekniğe bakmak gerekmektedir.

Teknoloji ile tarihsel ve toplumsal değişim arasındaki ilişsinin ne olduğu tartışmasında pek çok insan düşünce üretmiştir. İnsanlığın gelişimi boyunca, gitgide artan bir şekilde yaşamın çok farklı yanlarının ve çehrelerinin teknolojikleşmesi konuyu önemli hale getirmiştir. Teknolojinin özelinde de iletişim teknolojilerinde yaşanan değişimlerin ne gibi toplumsal, kültürel, ekonomik ve siyasal etkileri olduğunu açıklamaya çalışan, teknolojik belirlenimci yaklaşıma göre iletişim araçlarının teknik aygıtı toplumsal ilişkilerin biçimlenmesinde kurucu bir rol oynamaktadır (Özçetin, 2018, s. 233). Teknolojik belirlenimciliğin bu bakış açısına yakın duran ve teknoloji ile medeniyeti eş tutan Baltacıŏglu'na (1950a, s. 56) göre, teknik; dini, hukuki, ahlaki, sanatsal herhangi bir sosyal gelişmeyi elde etmek için doğa materyallerinin akılla düzenlenmesinden meydana gelen ve sosyal bir verim elde etmeye yarayan bir araçtır. Teknik, toplumla birlikte doğmuş ve kolektif zihniyetin özel bir manzarası olarak belirmiştir. Teknik ilim, rasyonel zihniyet ve rasyonel bilgi ile birlikte ilkel toplumların medeniyet hamlesini taşır. Teknik, önceleri insana ve ruhuna yapışık bir faaliyetten ibaretken, gitgide buralardan ayrılmış, kendi kendine yeten, müstakil bir varlık haline gelmiştir. İnsanın icadı olan teknik, artık insanın yerine geçmiştir ve ona hâkim olmaya başlamıştır (Baltacıoğlu, 1939, s. 293-394). Baltacıŏlu, bu yorumuyla, 1960'larda Marshall McLuhan'1n, tüm medyanın toplumu tepeden tırnağa değiştirdiği fikrini, öncelediğini söylemek mümkündür. Baltacıoğlu'na göre, ekonomik, siyasal, toplumsal yapılarla teknoloji arasında önemli ölçüde 
bir dayanıșma vardır. Toplumsal dönüșümün temelindeki belirleyicilerden biri teknoloji yani iletişim araçlarıdır.

\section{1. İletişim Araçları ve 'Değer Anarşisi'}

Üretim ilişkileriyle birlikte biçimlenen kapitalizmle, yalnızca insanların günlük kullanımına yönelik ürünler değil, aynı zamanda insanların duygularına ve bilincine yönelik ürünler de üretilmeye başlanmıştır. Kapitalizmin ticaret ve kazanç üzerine kurulu işleyişi insan ve toplum yaşamının tüm kesitlerine etki eder, insana dair ne varsa (değerler, gereksinimler, haz duygusu, düşler, hayaller, idealler gibi) ticari kazanç ilişkileri içerisine çekilerek kullanılır. Kitle iletişim araçlarını, yeni dönemin ticari kültür ortamının başat aygıtları olarak ele alan Frankfurt Okulu düşünürleri bu noktadan hareketle tezlerini oluşturmuştur. Onlara göre, kapitalist sistem yaşamın tüm alanları gibi kültür alanını da ticarileştirmiştir (Güngör N. , 2011, s. 83). Kültür ve kültür ürünleri, tekrarlardan oluşan, tek tip özelliktedir ve artık özgünlüğünden bahsedilmesi mümkün değildir.

1930'lu y1llarda Frankfurt Okulu temsilcilerinin bu düşüncelerine şaşırtıcı derecede yakın fikirleri olan Baltacıŏlu'na (1967, s. 18-19) göre, toplum her şeyin hızla üretilip tüketildiği yozlaşmış bir ortamdır. Yozlaşmış bu ortamda değerli olanların yerine değersiz olanlar, toplumun asıl değerleri olarak ortaya çıkmaktadır. Gerçekte toplumun değeri olmayanların değer haline getirilmesinde iletişim araçları da önemli rol oynamaktadır; çünkü sinema, radyo gibi araçlar, ürünleri alır, kullanır, hızla tüketir ve tüketilmesine de yardımcı olurlar. Her şeyin hızla tüketilip yozlaştırıldığı bu durum 'değer anarşisi'dir. Değer anarşisini sürdürenler (1967, s. 18-19) ise, 'değer kalpazanları'dır:

\footnotetext{
Topluluk içinde öyle insanlar vardır ki, belli başlı bir değer sahibi olmamakla birlikte, yüksek değer sahibi insanlar gibi ün salmışlardır, kendilerini büyük şair, büyük aktör, büyük rejisör olarak tanıtmasını bilmişlerdir. Bu başarı sebepsiz değildir. Onlar, görenek, telkin, propaganda, reklam nedir çok iyi bilen kimselerdir. Her fırsattan yararlanıp gazetelere demeç vermesini çok iyi bilirler. Bu insanlar, değer piyasasına kalp akçe süren kalpazanlardır.
}

Baltacioğlu (1994, s. 343-345), 'değer anarşisi'ni, kitlesel olarak üretilmiş ürünlere hayranlık olarak da tanımlamakta ve buna 'zevk milliyetçiliği' de demektedir. 'Zevk milliyetçiliğgi' kitle iletişim araçları aracılığıyla pekiștirilmektedir. İletişim araçlarıyla aktarılanlar toplumda belli imajlar yaratır. İletişım araçlarıyla aktarılan imgelerle, insanların tüketim eğilimleri körüklenmektedir. Ürünler insan gereksinimlerini ve arzularını karşılamak 
için değil, kazanç elde etmek, kapitalist pazarda büyümek için üretilir, tüketime sunulur ve böylece zevk milliyetçiliği oluşur. Baltacıoğlu, imgelerin yaratımını moda endüstrisinden örnekle açıklamaktadır. Moda ile ilgili zevk milliyetçiliğini Batı yaratmıştır. Batı modası bayağı bir kapitülasyondur. Bu moda toplumda Tanzimat'tan itibaren hızla artmıştır. Aydınlar, moda üzerinden zevk milliyetçiliğini toplumun milli kültür tarihine sokmuştur. Tüketimin hızlı artışının eleştirişini bir anekdotla örnekler: "Bir Türk kadını yakın erkek arkadaşlarından birinin ayağındaki köylü işi yün çoraba bakıp sormuştu: 'Karın bu çorabı giymene Nasıl müsaade ediyor?’ Arkadaşım şu cevabı vermişti: ‘Çünkü karımın zevki yüksektir’”. 'Değer anarşisi'den kurtuluş için sunduğu çözüm önerisine göre; siyasal, ekonomik şartların üzerinde durmak yerine, sosyal koşullar düzenlenmeli ve özellikle toplumun bilinç düzeyi üzerinde durulmalıdır. Toplumun bilinç düzeyinde aydınları etken olarak görmektedir ki bu noktada da daha önce benzerlik gösterdiği vurgulanan Frankfurt Okulu düşünürleriyle taban tabana zit fikir önermektedir. Okulun temsilcilerine göre, kültür endüstrisinde gediksiz bir sistem vardır ve bunun nedeni sadece çağdaş teknik olanaklar değil, aynı zamanda ekonomik ve yönetsel yoğunlaşmadır. Bu noktada kitleleri nesneye dönüştüren sisteme bakılması gerekmektedir (Özçetin, 2018, s. 179). Baltacıoğlu'na (1950a, s. 148-149) göre, kültürün yozlaşmasının anlaşılması için bilince bakılmalıdır. Toplumun bilincine etki eden aydınlar ele alındığı zaman kültürün yozlaşması da anlaşılacaktır. Aydınlar, Batı ile kurdukları ilişki sonrası, topluma değer anarşisini getirmektedirler. Baltacıoğlu, bu düşüncesini danstan örnekle açıklamaktadır: Milli kültürlerini bilmeyen ya da unutan aydın, kendi halk danslarına gülerken Batı'nın danslarını önemsemektedir. Bu durumda öncelikli olarak aydınlara hakiki olan halk kültürü yeniden hatırlatılmalı ya da baştan öğretilmelidir. Böylesi bir önerinin mümkün olamayacağı bir durumda ise orta bir yol olarak Batı'nın dans tekniği ile halkın dans gelenekleri biraraya getirilmelidir; bu sayede 'değer anarşisi'ni topluma yayan aydın bilinci ve onun kullandığ1/yararlandığı araçların yapısı da değişecek bu sayede toplumda değer anarşisi çökecektir.

\section{GAZETECILIIĞE DAIIR GÖRÜȘLERİ: "TARAFSIZ GAZETE YOKTUR"}

Türk modernleşme sürecinde gazete, geri kalmış ülkede geniş halk topluluğunun aydınlanması ve bilgi edinmesini sağlayan başlıca araçtır. Doğu kültürüne bağlı kalarak, Batı'nın medeniyeti alınarak toplumun ilerlemesine en büyük yardımcı, kaçınılmaz olarak 
gazetedir. Gazete esasında tek başına yeniliği ve gelişmeyi ifade etmektedir. Küçük olayları aktararak dünya ile ilişki kuran, faydalı bilgiler veren ve okumayı geliştiren bir araç olmanın ötesine geçerek gerçek anlamda fikir tartışmalarının yapıldığı bir ortam olmuştur (Gündüz, 2018). Medeniyetin takip edilip topluma uygulanması gerektiğini belirten Baltacıŏ̆lu'na (1942, s. 2) göre gazete, medeniyetin önemli örneklerinden biridir. Gazete, her şeyden önce günlük olayları ve gerçeği kovalayan araçtır. İster günlük olsun, ister haftalık olsun, ancak gerçek kovalanırsa gazete oluşur. Gazetenin günlük olaylar karşısında pasif kalması imkânsızdır. Her gazetenin politik, sosyal görüşü ve anlayışı vardır. Bu nedenle her gazete, ister istemez, aynı siyasi veya sosyal görüşü belirten yazıların ve yazarların toplandığı yer olmak zorundadır ve bu zorunluluk dolayısıyla da 'tarafsız bir gazete' iddiası pratikte boş bir iddiadan farksizdir.

Baltacıŏlu, Türk gazeteciliğini dönemsel özelliklerine göre; öğretici gazete safhası, hava yaratma gazete safhası ve eksperler safhası olarak üçe ayırmaktadır. Avrupa için basın, haber veren, eleştiren, yönetimle halk arasında bir köprü işlevi görüp fikirlerin yayılmasında bir araç işlevi üstlenirken işin arka planında sosyal kurumlar ve aydınlar vardır. Buna karşılık Osmanlı' da yeniliğin, gelişmenin kaynağı basındır, kamuoyu basının etrafında oluşmuş, okuma nesnesi olarak okuma alışkanlığına katkıda bulunmuş, aydınların yetişmesinde rol almış, kitabın dolduramadığı boşluğu doldurmuştur (Gündüz, 2018, s. 42). Ayrıca ilk dönem gazeteler haberden çok eğitim aracı olarak kendilerini sunmuşlardır. Ceride-i Havadis gazetesi, önceliğini eğitime vermiş örneklerdendir. İlk sayısının önsözünde eğitimin, insanlığın başlıca çabası olması gerektiği ve gazetenin de buna katkısının inkâr edilemez olduğu belirtilmektedir (Koloğlu, 2006, s. 30). Baltacioğlu (1943, s. 2), bu ilk dönem gazeteciliği, 'öğretici gazete’ dönemi olarak tanımlar. Bu dönemde gazete, kitap gibi öğreticilikle işe başlamıştır. Bu anlamda ilk gazeteler, topluma haber ve yararlı bilgileri yayınlama aracı olmuştur. İkdam gazetesi, bu dönemin en iyi örneğidir: "Meşrutiyet'ten önce ve sonraki dönemde sayfalarında, en önemsiz zabıta olaylarından, dış politika olaylarına kadar bol haber, patates ekiminden İsviçre'deki köy postalarına kadar değişik konularda başyazılar bulunmaktadır”. İlk dönem gazeteciliğin kırklı y1llarda kaybolduğunu üzülerek belirten Baltacıŏlu (1943, s. 2) Cumhuriyet gazetesinin hem eğitim hem haber özelliğini koruması nedeniyle az sayıdaki öğretici gazeteden biri olarak anılabileceğini belirtmektedir. 
Gazeteciliğin ikinci dönemini Baltacığlu (1943, s. 2) 'hava yaratma gazeteleri' olarak tanımlamaktadır. Türkiye'de Demokrat Parti'nin iktidara gelmesinden sonra, görece ekonomik gelişmenin başlaması, yeni teknolojilerin ülkeye getirilişi ile birlikte gerçekleşmiştir. Türk basını bu yeni anlayışla kabuk değiştirirken, yeni ve renkli gazetecilik teknolojisine yatırım yapmıştır. Basım teknolojilerinin gelişmesiyle birlikte tirajlar artmış, gazetenin içeriği ve kalitesi iyileştirilmiş, aynı zamanda reklam pastası büyümüş, haberleşme, ulaştırma altyapıları geliştirilmiş ve gazetecilikten para kazanma yolları açılmıştır (Tokgöz, 2000, s. 31). 'Başyazıya dayanan gazete' anlayışından 'habere ve resme' öncelik tanıyan anlayışa geçilmiştir. Halk, yorumlarla yönlendirilmek yerine, haberi okuyup kendi yargısına varacağı gazetecilikten hoşlanmıştır. Sonuçta, herhangi bir iç ve dış olay veya herhangi şahıs ve eser üzerinde konunun ilgisini ve merakını uyandırmak için tasvirler, mübalağalar yaparak hava yaratan gazetelerin satışları artmış, bu sayede de okuyucu sayısı genişlemiştir (Baltacıoğlu, 1943, s. 2). Baltacioğlu'nun 'hava yaratma gazetesi' olarak betimlediği şey esasında 1830'larda Amerika'da yaygınlaşmaya başlayan magazin gazeteciliğidir. Magazin gazeteciliği "insanları bilgilendirmekten çok hoşça vakit geçirtmeyi, oyalamayı amaçlayan, sayfa düzeni bol resimli, büyük puntolu, az haberli, anlatımı çok basit, haber konuları ise çok çeşitli olan bir gazetecilik türüdür” (Uzun \& Alemdar, 2013, s. 211). Hava yaratma dönemi, Baltacığlu (1943, s. 2) için gazeteciliğin romantik aşamasıdır. Bu dönemde, gazetelerin amacı, gerçeği tarafsız anlatma ve açıklama olmayıp bu gerçeğin ilgi ve heyecan lehine romanlaştırılmasıdır: "Gerçek ihtirası taşımayan, duygu ve ihtiras tadına alışık ruhlar için romantik yayınlar kamçılayıcı bir etki yapar. Türk gazetelerinin hemen hepsi bu romantik safhada bulunmaktadır. Bu temayülün en mübalağalı şekilleri tarihi roman, mahkeme, mülakat konuları üzerine yazılan yazılarda görülür’. Bu noktada şunu belirtmek gerekir; Ruhdan Uzun ve Kormaz Alemdar'a (2013, s. 208) göre, Türkiye'de magazin gazeteciliğinin ilk denemeleri 1960'larda başlamıştır. Profesyonel olarak magazin gazetecilik türü altmışlarda yaygınlaşmaya başlamış olsa da Baltacıoğlu'nun bu türün özelliklerini çok önce gözlemlemiş ve bunun üzerine fikirler geliştirmiş olduğunu belirtmek gerekir.

Gazeteciliğin son dönemini ‘Eksperler safhası’ olarak tanımlayan Baltacıoğlu (1943, s. 2) bu tanımı yaparken aslında araştırmacı gazeteciliğin özelliklerinden bahsetmektedir. Araştırmacı gazetecilik, "bir olayın derinlemesine araştırılması, belgelenmesi, arka planda olup bitenlerin açığa çıkarılmasını anlatan bir gazetecilik türüdür... Araştırmacı gazetecilik uzun 
zaman, uzmanlık, deneyim, bilgiye ulaşma yöntemleri konusunda bilgi ve eleştirel bir bakış açısı gerektirmesi nedeniyle rutin gazetecilik uygulamalarından ayrılır" (Uzun \& Alemdar, 2013, s. 211). Baltacığlu, Yeni Adam dergisinde kaleme aldığı Türk Gazeteciliği (1943, s. 2) isimli makalesinde 'eksperler safhası'nı anlatırken araştırmacı gazetecilikten detaylı biçimde bahsetmektedir: Bu aşamada olaylar tarafsız ve gerçeğe uygun olarak açıklanır. Realist olan bu aşamada bir gazete, olayları bildirmekle ve onların etrafinda duygu ve heyecan dalgaları yaratmak kalmaz, bu olayları bilimsel ve objektif biçimde açıklamaya çalışır. Her olay konusuna göre uzmanı tarafından incelenip izah edilir. Amerikan gazeteciliği bu ileri aşamayı yaşarken Türkiye'nin henüz bu aşamaya gelmediğini de belirtir. Amerika'nın tüm gazete ofislerinde uzmanlar çalışmaktadır. Türkiye'de gazetelerin çoğunda, adliye, meclis, askeriye, edebiyat, spor gibi alanlarda uzmanlaşmış muhabirler olsa da uzmanlaşmadan kasıt muhabirlik düzeyinde gazetecilik değildir. Baltacıŏlu'na (1943, s. 2) göre muhabir sadece haber yapmaktayken kendisinin bahsettiği uzmanlaşmada toplumun her birimiyle ilgili (fert, aile, meslek, şehir, devlet gibi) detaylı açıklama, tartışma ve yorumların yapıldı̆̆ı araştırmacı gazetecilik söz konusudur. İşbölümüne yer verilmemesi ve uzmanların yerine sadece muhabirin istihdam edilmesi, gazetelerin hava yaratma döneminde kalmaları gibi nedenlerle Türk gazetelerinin üçüncü aşama olan araştırmacı gazetecilik yani 'eksperler safhası'na erişemediğinin altını çizer.

\subsection{Gazetecilikte Dil}

Cumhuriyet'in ilk yıllarındaki aydınlar gibi 'yeni bir toplumsal kimlik' arama ve üretme faaliyetini önemseyen Baltacıoğlu (1932a, s. 137-142) bu yolun Cumhuriyet'in yeniliklerinden geçtiğini düşünmekte ve bu yeniliklerden biri olan dil devrimine destek vermektedir. O'na (1967, s. 28-32) göre dil, toplumsal kalkınmanın etkenlerinden biridir. Dilsiz kişilik olamayacağı gibi, dilsiz milliyet de olamaz; çünkü dil yalnız anlaşma aracı değil, aynı zamanda kaynaşma etkenidir. Dil ile taşınan bütün bir milliyetin kalıtıdır. Dil toplumun hem akıl varlığını, hem de vicdan varlığını taşır. Dilde olan yalnız özler değildir. Dilinde gerekli özleşme, millileşme, bilimleşme hareketini yapamayan milletler medeniyet getiren dillerin salgını altında yok olurlar.

Dilin bir kültür, bir milliyet hazinesi olduğunu gösteren gerçeklerden biri de dil üzerinde, dil aracılığıyla bir takım güzel sanatların var olmasıdır: Şiir, nesir, tiyatro, hitabet, mizah sanatları ve gazetecilik bir bakıma dil sanatlarıdır. Dil sanatı olarak gördüğü gazetecilikte 
dil kullanımına da özel olarak kafa yorulması gerekmektedir. Dil reformunun topluma sızmasında gazetelere görev düştüğünden bahseden Baltacıoğlu'na (1936b, s. 2) göre, gazeteci, eskinin softa dilini ve Osmanlı'nın zengin dilini atıp halk dilini almalı, onu Batı'nın tekniğiyle kullanmalıdır çünkü dil devrimi bir yüz inkılabı olmayıp bir gövde inkılabıdır. 1935 tarihli Basın Kongresi ${ }^{6}$ 'nde öz Türkçe kelimelerin gazete, dergi yayınlarında daha sık kullanılması ile ilgili karar alınmış ve toplantıya katılan gazeteciler de bu kararlara imza atmıştır. Kongrenin ardından öz Türkçe akımı yaygınlaşmış ve bir süre devam etmiş ancak bir süre sonra eski kelimeler, Arapça ve Farsça kullanımlar yeniden belirmeye başlamıştır. Bu yapılanlar yenilik hareketine karşı gelmenin yanında gazeteciliğe ve halka ihanettir (Baltacıŏlu, 1936a, s. 2).

Baltacıoğlu (1936b, s. 2), otuzlu yıllarda halkın gazete okumamasının nedenleri arasında, gazetelerin dil inkılabını içselleştirmemelerini ve uygulamamalarını görmektedir. $\mathrm{Bu}$ dönem gazetelerin öz Türkçe dil yapısını kullanmayıp, Osmanlı Türkçesi’ni kullanmaları nedeniyle, halkın okumaya olan ilgisini körelmiştir. Bu körelmeye çözüm olarak da şunu önerir: “En yenisinden en eskisine dek, Orhan Veli'lerin, Yunus Emre'lerin, Orhon Yazıtları'nın Türkçesine, gelenekli Türkçeye, Türkçeyi Türkçe yapan dil, zevk geleneklerine dönülmelidir”.

Gazetelerde ve diğer edebi eserlerde öz Türkçe dil kullanılmamasının iki nedeni olduğunu belirten Baltacıŏ̆lu'na (1936b, s. 2) göre, ilk neden, toplumda sırtını hilafete veren medreseli grubun halk dilini geri, değersiz bulması ve bu nedenle de şeriat dilini temiz dil olarak kabul etmesidir. İkinci neden ise, 'saltanat burjuvaları'dır. Para kazanma hırsı, yaşama kolaylığı, tembellik gibi özellikler insan istismarını yaratır ve buna yardım eden 'saltanat burjuva'ları, sırtını padişahın itibarına, zaferlerine, politikasına dayayarak halkı değersiz görür. Bu burjuva sınıf için değerli, geçerli olan dil, saray, ekâbir ve salon dilidir. Halkın gündelik dili değersiz ve basittir. Yaşamlarının tamamını veya bir kısmını bu sayılan gruplarda geçiren kişiler gazetecilik mesleğinin de içindedir ve yayıncılığı belirlemektedir. Önceki neslin eğitimi ile terbiyesi, medrese ve burjuva prensiplerine göre olmuştur. Bu nesil otuzların gazetecilik pratiklerini de belirlemiştir. Medresenin eski dil ile baskı altında tuttuğu halk dili, para ve mevki

\footnotetext{
${ }^{6}$ Cumhuriyet tarihinde Türk basının sorunlarının belirlenip, tartışıldığı, çözülmesine yönelik kararların alındığ i ilk etkinliktir. Cumhuriyet'in ilanından sonra yaşanan toplumsal gelişmeler basına ilgili düzenlemeler yapılmasını da zorunlu hale getirmiştir. Basın kongresi de bu çalışmaların önemli yansımasıdır. Özellikle 1928'de Latin Alfabesinin kabul edilmesiyle birlikte okuryazarlık oranı artmış, gazete daha geniş kitlelere ulaşmıştır. Basının yönetim organı olarak görülen Matbuat Umum Müdürlüğ̈̈, Türk basınının sorunlarını kabul edip, okuyucuların da nabzını ölçerek, basınla ilgili tüm kurumları kapsayacak şekilde, bütünsel bir etkinlik gerçekleştirmiştir. Belirlenen hedeflere tam anlamıyla ulaşılamasa da kongre başlangıç olması açısından son derece önemlidir (Eraslan, 2010, s. 151).
} 
için lise ve üniversite eğitimini elinde tutan burjuvalarca Avrupa kültüründen mahrum bırakılmış, sanat ve bilgi dili haline gelememiştir. Halk masallarında ve halk şiirlerinde olduğu gibi iptidai güzellik maalesef naiflik çağında kalmıştır. Yeni dönem gazetecilerin bu durumu fark etmeleri, dillerini özleştirmeleri ve Batı tekniği ile bunları birleştirmeleri gerekir. $\mathrm{Bu}$ çözüm önerileri hayata geçirildiğinde gazetecilik, softa ve burjuva dilini bırakarak halkın anlayacağı, okuyabileceği dile sahip olabilecektir.

Gazetelerin toplumda yaygınlaşmasında, gazetecilerin farkındalıklarının arttırılması gerektiğini ve bunun için de eğitimin şart olduğunu işaret eden Baltacioğlu'na (1932b, s. 6365) göre, bir gazetecinin ve gazetenin başarılı olabilmesi için gazetenin ne zaman, ne kadar çıkarılacağının, nerede, kime, nasıl satılacağının bilinmesi gerekir. Baltacığlu’nun yazdığı bu fikirler, dönemin yönetimi tarafından da fark edilmiştir. Tek parti yönetimi, gazetecilerin de en az öğretmenler kadar eğitim görmesi gerektiğine inandığından, sorumlu yazı işleri müdürleri için lise ya da yüksekokul bitirme zorunluluğunu 1931 basın yasasına eklemiştir (Alemdar \& Erdoğan, 1998, s. 7).

Baltacıoğlu (1967, s. 127-132), gazetecilik mesleğinin okulda eğitim alındıktan sonra icra edilmesinin önemi vurgularken, pratikteki usta-çırak ilişkisinin de eğitim için zorunlu olduğunu belirtir. Gazetecilik mesleği, iyi patron, iyi usta üzerine kurulu olduğu kadar iyi usta da iyi işçi üzerine kurulur. Mesleğe önce iyi işçi olmakla başlanmalı bunun içinde önce eğitim alınmalıdır. Yalnız, alınan bu eğitimin çoğunlukla iş dünyasıyla örtüşmediğini de göz önünde tutmak gerekir. Bu nedenle stajyerlik önemlidir, ancak iş dünyasında da staj yapan öğrencilere fazla değer verilmez. Bu adet çok da temelsiz değildir çünkü okuldan yeni çıkan gazeteci okulda birçok kitap bilgisi öğrenmiş olsa bile iş dünyasında çırak olarak değersizdir. Gazeteciliğin usta-çırak ilişkisinde, çıraklık okulda kazanılan fikirlerin bir devamı veya uygulaması değildir. Okulda öğrenilen bilgiler gazetecilik için temel tuğlalar ise çıraklı da bu tuğlaların yerleştirilmedir.

\subsection{Ill Gazeteleri}

Yerel basın, sınırları dar ve tanımlanmış bir yörede, yöre halkını bilgilendirmeye, eğitmeye, eğlendirmeye böylece kamuoyunun serbestçe oluşmasına katkıda bulunmaya çaba gösteren kitle iletişim araçlarıdır. Yalnızca belirli bölgede yayımlanan ve okunan, ulusal gazetelerden farklı olarak yerel haberlerin ve konuların yer aldığı gazeteler (Erdem, 2007, s. 
112) olarak tanımlanmaktadır ki bu 'İl gazeteleri' (1950b, s. 2) başlıklı yazıyla Baltacıoğlu'nun da hemfikir olduğu bir tanımdır. Yerel gazeteleri 'il gazeteleri' olarak isimlendiren Baltacioğlu'na (1950b, s. 2) göre, 'il gazeteleri’ her şeyden önce bulunduğu ile ait gazetelerdir. Bunların asıl görevleri memleket ve dünya haberlerini vermek değil, kendi illerinin ihtiyaçlarını kendi dilleriyle belirtmektir. Bu nedenle de 'il gazeteleri’ ülkedeki şehirlere dair birçok şeyden tam ve doğru olarak haber vermenin yanında yerel yönetimlerin hizmetlerinin duyurulmasıyla birlikte yerel yönetim-yurttaş ilişkisinin saptanmasına da katkıda bulunur. Bulunduğu bölgenin toplumsal, kültürel, sosyal gelişimine ve eğitimine katkıda bulunmaya yardımcı olan yerel basın, bulunduğu sosyal çevre ve dolaylarının çeşitli sözlü ve yazılı geleneklerini toplayıp sayfalarına geçirerek folkloruna de hizmet etmektedir. Aynı zamanda 'il gazeteleri' yerli yeteneklerin ilk belirdiği yerlerdir. Bir köyün, bir bucağın, bir ilçenin bir kıyısında yetişen gençler, çekingen kalemlerinin ilk denemelerini bu 'il gazeteleri' nde yaparlar. Bu denemelerden cesaret alan birçok genç yetenek bugünün yazarları arasında yerini almışlardır.

Baltacıoğlu (1950b, s. 2) toplumsal açıklamalarında kullandığı kültür ve medeniyet ayrımını il gazeteleri ve yaygın basın açıklamalarında da kullanmaktadır. Yaygın basın ile 'il gazeteleri' arasında farklılıklar kültür ve medeniyet ayrımı gibidir. 'İl gazeteleri', her yerli ve halkın olan şey gibi, ulusal bir karakter taşır. Bu karakter, büyük şehir gazetelerinde bulunmaz. ‘İl gazeteleri’ kültür organı olarak işlev görür yani kültürcüdür, büyük şehir gazeteleri ise medeniyetçidir. 'İl gazeteleri’ iyimserdir, gelenekçidir, halk ve özellikle köylüye çok yakındır. Büyük şehir gazeteleri, kötümser, moda düşkünüdür, halka ve özellikle de köylüye bir hayli uzaktır.

\section{DERGİCILIKK İLE İLGILİ GÖRÜŞLERI: "DERGİCİLIKTE UZMANLAŞMA ŞART"}

On dokuzuncu yüzyılda Osmanlı'da etkin hale gelen fikir akımlarının etkinleşmesinde gazetelerle birlikte ortaya çıkan ve yaygınlaşan dergiler, ideolojik, siyasal fikirlerin yayılmasında önemli rol oynamışlardır. Cumhuriyet'in ilk yıllarından günümüze kadar dergicilik bir yönüyle ideolojik yönelimini sürdürmüş, bir yönüyle de varoluşunun asıl amac1 olan kültürel, sanatsal, toplumsal, bilimsel tartışmaları sürdürerek ilerlemiştir. Bir toplumda süreli yayınının mutlaka olması gerektiğini belirten Baltacığlu (1942, s. 2) için dergi, her 
günkü olaylarla doğrudan ilgisi olmayan ve hemen hep soyut fikirleri taşıyan, zaman ve yer bağlılığı bulunmayan yazıların aralıklı dönemlerde yayınlandığg yerdir. Dergi, hem gazeteden hem de kitaptan doğası gereği ayrılmaktadır. Bu anlamda da gazeteden farklı olarak günceli kovalamamalıdır; çünkü aktüaliteyi kovaladığı zaman gazete haline gelir. Dergi, toplumun gelişimine katkıda bulunan kitaplardan da farklıdır. Kitaba göre, hacmen küçüktür, hafta, ay ya da yıl gibi zamana bağlıdır. Az ve öz yazılar vardır, bununla birlikte dergilerde, kitaplardaki gibi kuramlardan, çeviri bilgilerden bahsedilmez ve bunlar aktarılmaz. Dergiler hayatın renklerini aktarmaya çalışır. Süreli ve zamanı yakalamak zorunda oldukları için ülkenin iç gelişmelerinin dişında uluslararası alandaki gelişmeleri gazetelerden farklı olarak haber biçiminde doğal gelişimleri, zihniyetleri ile takip edip yazarlar (Baltacioğlu, 1932b, s. 263267).

Gazetelerin güçlü etkisi nedeniyle okur, çoğunlukla kendisine yakın düşünce ve görüşleri yansıtan gazeteye yönelmektedir. Dolayısıyla okur üzerinde, tümüyle yeni bir etkinin yaratılması mümkün değildir. Gazetelerde yapılan çoğunlukla var olan etkinin pekiştirilmesidir. Oysa dergiler açısından aynı durum geçerli değildir; çünkü dergileri satın alan okurun asıl amacı beli alandaki konuların gelişimlerini takip etmek, sanatsal etkinlikleri ve tartışmaları izlemektedir. Dergi, aynı zamanda, alınıp satılmasıyla ve sahiplerine sağladığı kazançla ekonomik; içeriği ve savunduğu görüşlerle politik; fikir akımlarını ve ideolojileri yönlendirmesiyle sosyolojik; reklamlar ve okuyucu algılaması üzerindeki etkisiyle psikolojik boyutlar içermektedir. Bu süreçte, okur, farkında olmaksızın dolaylı yollardan bir takım ideolojiye maruz kalmakta; hatta bunları içselleştirmektedir (Güngör \& Tellan, 2000, s. 163164). Bu nedenle de "dergiler sıradan insanın gündelik yaşamından da bahsetmeli, böylece yaratılmak istenen fikir ve gelişmeler için topluma etki gücü arttırılmalıdır" (Baltacıoğlu, 1932b, s. 77-79).

Kişilere etki etmesi ve böylece gelişmenin sağlanması için dergilerin tematik olması üzerinde duran Baltacıoğlu (1932b, s. 78), tematikleşme fikrini dini içerikli dergilerle ilgili tartışmasında vurgulamaktadır. O’na (1967, s. 108-109) göre, dinde reform yapılırken, dinin anlaşılması ve yeniden düşünülmesinde dergiler önemli araçlardır. Bu nedenle gelişmeler için uzmanlık alanlarına yönelik dergiler çıkarılmalıdır. Türkiye'de birkaç tane din dergisine ihtiyaç vardır. Bu ihtiyaç tartışılacak bir konu değildir. Dinin göze, akla, mantığa hitap eden niteliği ile içe, duyguya, gönüle yönelik bir niteliği vardır. Bu nedenle bilim anlayışının eseri olarak 
dergiler, yaşamda dinin bir kalkınma aracı olarak kullanılmasını sağlayacaklardır. Toplumun kalkınmasında din dergisi, sanat dergisi gibi tematik dergilerin büyük rolü olacaktır.

Türkiye'de tematik dergicilik açısından, sanat dergisinin olması gerektiğini vurgulayan Baltacıoğlu (1932b, s. 78), sanat dergisinin hangi konuları ele alması gerektiği ve biçiminin de ne şekilde olacağını şu cümleleriyle ifade etmektedir:

Türkiye'nin sanat mecmuası Avrupa ve Amerika kıt'alarındaki yeni san'at cereyanları için bir ayna olmalıdır. Fakat Türk memleketinin san'at hususundaki telakkilerini, zihniyetlerini de oralara aksettirmelidir. Diğer memleketler san’at mecmualarının şeklini hemen tespit etmişlerdir. Türk mecmuası da bunlardan ayrı gayrı olmamalıdır. Mecmuanın başlıca mevzuu asri hayatın san'at cereyanları olacaktır. Millletlerde bu cereyanların en canlı surette meydana gelmesi sergiler vasıtasiyle oluyor. O halde beynelmilel sergiler hakkında etütler neşretmek bu mecmuların başlıca bir vazifesi olacaktır. Ayrıca yeni cereyan mümesillerinin hayatı ve eserleri hakkında tetkiklere lüzum vardır. Türkiye'deki yeni ressamlık, mimarlık, tezyin san'atları telakkileri nasıl değişiyor, bunları da tetkik etmelidir. Mecmuanın bir de pedagojik neşriyatına mahsus sahifeleri olmalıdır. Bununla san'at cereyanının yapılamasına hizmet edilecektir.

Toplumda değişen eğilimler ile sosyal ve kültürel yaşamdaki değişlikler dergicilikte uzmanlaşmayı getirmiştir (Balta Peltekoğlu, 1995). Baltacıoğlu'nun da toplumdaki değişiklikleri gözlemleyerek dergilerin günlük yaşamda din, güzel sanatlar, fen, teknoloji gibi uzmanlaşmaya gidilmesi gerektiğini belirtmesi ve bu dergilerin içerik, biçim açısından nasıl olması gerektiğine değinmesi dergi yayıncılığının gelişmesine önemli bir katkıdır.

\section{SONUÇ}

Cumhuriyet'in erken dönemine denk gelen yaşamıyla, İsmayıl Hakkı Baltacıoğlu, çağdaşları gibi ülkenin toplumsal sorunlarını anlamaya, çözmeye çalışmış ve dönemin belirgin özelliği olan yeni toplum yaratma anlayışından etkilenmiştir. Çalışmalarında iletişim disiplinine ve kitle iletişim araçlarına yer vererek bu alana katkı sağlamıştır. Maddeci akımlara karşı olan ve manevi değerlere önem veren Baltacıoğlu, yeni Cumhuriyet'in inşasında kitle iletişim araçlarını modernleşmenin vazgeçilmez unsuru olarak görmüştür. Türk-İslam kültür ve kimliği içinde kalınarak Batı'nın endüstrisini, teknolojisini ve bilimin alınması gerektiğini önermiş; bu noktada Batı'nın gazetesi, dergisi ve bunların teknolojisinin alınması, içerikte ise Türk kültür ve değerlerine bağlı kalınması vurgusunu yapmıştır. Bu uygulamanın sonucu ise 
medenileşmiş bir Cumhuriyet olacaktır. Baltacıoğlu, bu görüşüyle iletişim teknolojisini uygarlık tarihinin merkezi olarak alan teknolojik belirlenimcilikle örtüşmektedir. Gazete, dergi gibi iletişim araçlarının gelişiminin, insan düşüncesi ve toplumsal örgütlenme biçimlerini değiştirdiğine inanmaktadır. Bu inancını 'değer anarşisi', 'değer kalpazanları' ve 'zevk milliyetçiliğii' gibi kavramları üzerinden örnekleyerek açıklamaktadır. Batı'da kültür endüstrisi tartışmalarının yapıldığ 1 yıllarda Baltacıŏ̆lu'nun kullandığı kavramların bu tartışmalara kısmen yaklaşması da oldukça çarpıcıdır.

Yeni kurulan Cumhuriyet için önemli birer eğitim araçları olarak gazete, derginin toplumu değiştireceğine inanan Baltacıoğlu bu yaklaşımıyla teknolojiyi mistifiye etmektedir. İletişim araçlarını mistifiye ederken aynı zamanda gazete ve dergiden Laswell'in belirttiğ iletişimin görevlerini yerine getirmesini de beklemektedir. Buna göre, gazete öncelikle haber vermeli bunun yanında insanların ilgilerini çekecek konuları içermeli ve bunu anlayabilecekleri dilde sunmalıdır. Sedat Simavi'nin gazetecilik eğitimini resmileştirmek için faaliyete geçtiği kırklı y1llardan bir on y1l kadar önce Baltacıoğlu'nun gazetecilik eğitiminden bahsetmesi ise öncül bir düşüncedir. Toplumda gazetenin okunması ve tirajlarının artmasında gazeteci eğitiminin önemine vurgu yapmıştır. Eğitimin sadece okulla sınırlı olmaması gerektiği, okulda öğrenilenlerin pratikte uygulanabilmesi için stajyerliğin de kaçınılmaz olduğunu belirtmesi ise gazeteciliği çok yönlü ve etkili görmesinden kaynaklanmaktadır.

Kamuoyunun oluşumunda vazgeçilmez öneme sahip olan yerel basın üzerine değinileri ise ilginçtir. Yerel gazetelerin giderek gücünü yitirmesini kültür-medeniyet ikilemi açısından ele alması ve bu süreçte ekonomi, siyaset gibi unsurları göz ardı etmesi sığ bir tartışma olmuştur. Ancak yerel basının gücünün azaldığı dönemlerde bunu fark etmesi, bu konuya çözüm getirilmesi gerektiğini söylemesi noktasında ise takdir edilmesi gerekir. Baltacıoğlu, gazetenin değinemediği farklı konu ve detaylara değinmesi açısından dergiciliği önemsemektedir. Kırk beş yıl boyunca aralıksız dergi çıkarması da bunun en iyi örneğidir. Baltacıoğlu, dergicilik alanında yenilikçiliğe açıktır. Farklı konuları ele alarak toplumdaki çeşitli insanlara ulaşacak tematik dergiler üzerine çok erken zamanlarda fikirler öne sürmüştür.

\section{EXTENDED ABSTRACT}


This study addresses the contribution of İsmayıl Hakk1 Baltacığlu, one of the intellectuals of the early Turkish Republic era, to communication studies with the studies he has made during a period of time in which communication had not been defined in Turkey as an independent research field. Like many intellectuals who studied in the field of sociology in the early years of the Republic, İsmayıl Hakkı Baltacıŏlu presented leading opinions with regard to communication science and communication means while he expressed his thoughts in his own specialization field. Baltacığlu, a supporter of the Republic regime, focused on the conventional and cultural modernization in creation of the new society. He explained the essence of cultural modernization through civilization and culture duality.

He mentioned that social development will be realized with civilization and emphasized that technology must be followed for civilization. He mentioned that mass media played a founding role in the civilization of society. He conducted detailed studies on culture and defined the degeneration of culture through its fast production and consumption with the concept of 'value anarchy'. He also counted the communication tools such as newspapers and magazines among the reasons for the formation of 'value anarchy' in the society, and made studies on these tools. He pointed out that the newspaper had not only a news feature, but also a tool to convey ideas and ideologies. He mentioned that the newspaper, which is an ideological tool, could not be neutral for this reason. He emphasized the language issue among his culturalist ideas, and pointed out that the language they use should be in Turkish in order to increase the reading rates of the newspapers. He stated that 'fanatic religionist' and 'sultanate bourgeois' language was used in the newspapers and criticized them seriously. He emphasized that the employees should be educated in order to maintain the dignity and legibility of the newspapers. He defined the training of newspaper employees as school and internships. In a period when the communication education has not been institutionalized in Turkey yet, he pioneered the field with his recommendations on journalism education. Actually, in the period when he shared his ideas, the management of the period added the obligation to finish high school or college for the managing editors to the Press Law based on these ideas, considering that journalists should be trained as much as teachers.

He divided the Turkish press history into three periods as "instructor, flaunting and experts". The first period he dealt with pointed out the first periods of country journalism and stated that newspapers inevitably played an educational role for the society in this period. $\mathrm{He}$ 
pointed out that the changing society and press life brought about the second term in journalism with the development of technology accordingly. The journalism he outlined for the second period corresponded to tabloid journalism, as named in the literature. What is interesting here is that Baltacıoğlu had foreseen such journalism much earlier although the concrete practices of tabloid journalism started in Turkey in sixties. The third period of press history has been defined as 'experts'. He addressed the necessity to research every cases in depth, to unveil their background, therefore the definite need for well educated journalists on the methods to get access to expertise, experience, information. The third period he referred was defined in the communication literature as investigative journalism. He touched on the fact that this period was run in the States and Europe systematically and he tried to draw road maps for its implementation in our country, as well. Based on traditional social perceptive, he considered local press as a substantial factor in preservation and improvement of folklore. He defined the local press, which contributes to social, cultural development and education of its region, as 'provincial newspapers'. He stated that the basic mission of 'provincial newspapers' was not only to convey the news of the country and the world, but also to specify the needs of their own provinces in their own language. He used the culture and civilization distinction, which he is using in his social statements, in provincial newspapers and common press releases, as well. 'Provincial newspapers' are public and culturalist. Metropolitan newspapers appeal to the public and are civilizationist. He has stated that periodical publications must definitely exist in society and he has also published magazines for long years. He distinguished magazines from books as magazines concentrate on the matters in depth and from newspapers as magazines do not chase current events. He emphasized that many issues, people and events in the national and international fields should be included in the magazine pages, thus, awareness of the society could be created in the reader. He also pointed out that the thematic journals should exactly be published, since the main purpose of the reader who buys the magazines is to follow the development of subjects in a certain field and to monitor artistic activities and discussions. Based on the above-mentioned thoughts, this study tried to reveal the contributions of İsmay1 Hakkı Baltacığlu to the communication sciences. 


\section{KAYNAKÇA}

Akgül, M. (2020). Mümtaz Turhan'ın Türk iletişim araştırmalarına katkıları. Selçuk Illetişim, 13(1), 338-353.

Akkanat, S. (2017). Kemalist modernizmin inşası ve gelenekçi-muhafazakarlık: İsmayıl Hakkı Baltacıoğlu ve terbiye düşüncesi. Tarih ve Gelecek Dergisi, 3(3), 236-247.

Alemdar, K., \& Erdoğan, İ. (1998). Cumhuriyet döneminde Türkiye'de bilim sosyal bilimler: iletişim. Ankara: TÜBA.

Althusser, L. (2007). Kapital'den Marx'ın felsefesine. L. Althusser, \& E. Balibar içinde, Kapital'i okumak (A. Ergüden, Çev., s. 21-108). İstanbul: İthaki Yayınları. doi:975-273$180-5$

Althusser, L., \& Balibar, E. (2007). Kapital'i okumak. (A. Ergüden, Çev.) İstanbul: İthaki Yayınları.

Altın, H. (2014). II. Meşrutiyet'ten Cumhuriyet'e İsmayıl Hakkı Baltacıoğlu ve onun eğitim ve eğitimci kavramları ile ilgili düşünceleri. Sosyoloji Konferanslart, 33(55), 219-252.

Aytaç, K. (2017). Köy enstitüleri ve İsmayıl H. Baltacığlu'nun değerlendirmeleri. Sosyoloji Konferanslarl(55), 351-367.

Balta Peltekoğlu, F. (1995). Dergiciliğin gelişimi ve Türkiye'de kadın dergileri. Marmara İletişim Dergisi(9), 113-139.

Baltacıoğlu, İ. (1932a). Mürebbilere. İstanbul: Suhulet Kütüphanesi.

Baltacıoğlu, İ. (1932b). Terbiye. İstanbul: Suhulet Kütüphanesi.

Baltacıoğlu, İ. (1936a, Temmuz 2). Öz Türkçe akını durdu mu? Yeni Adam(131), s. 2.

Baltacıoğlu, İ. (1936b, Eylül 3). Türkçesi olmayan gazeteciler. Yeni Adam(140), s. 2.

Baltacıoğlu, İ. (1939). Sosyoloji. İstanbul: Sebat Basımevi.

Baltacığlu, İ. (1942, Ekim 15). Gazete-dergi yeni adam hangisi. Yeni Adam(407), s. 2.

Baltacıoğlu, İ. (1943, Aralık 9). Türk gazeteciliği. Yeni Adam(469), s. 2.

Baltacıŏlu, İ. (1950a). Halkın evi. Ankara: Ulus Basımevi. 
Baltacioğlu, İ. (1950b, Nisan 27). İl gazeteleri. Yeni Adam(647), s. 2.

Baltacıoğlu, İ. (1967). Kültürce kalkınmanın sosyal şartları. İstanbul: Talim Terbiye Dairesi Yayınları.

Baltacıoğlu, İ. (1994). Türke doğru (3. Baskı b.). Ankara: Atatürk Kültür, Dil ve Tarih Yüksek Kurumu Atatürk Kültür Merkezi Yayını.

Best, S., \& Marcus, S. (2009). Surface reading: An introduction. Representations, 108(1), 121.

Bewes, T. (2010). Reading with the grain: A new world in literary criticism. A Journal of Feminist Cultural Studies, 21(5), 1-33. doi:10.1215/10407391-2010-007

Bourse, M., \& Yücel, H. (2012). İletişim bilimlerinin serüveni. İstanbul: Ayrıntı Yayınları.

Bulut, S. (2012). Mübeccel Kıray'ın iletişim alanına katkıları. İstanbul Üniversitesi İletişim Fakültesi Dergisi(15), 285-309.

Eraslan, H. (2010). İlk basın kongresi (1935). N. Güngör, \& N. Güngör (Dü.) içinde, Cumhuriyet döneminde iletişim kurumlar, politikalar (s. 151-159). Ankara: Siyasal Kitabevi Yayınları.

Erdem, B. (2007). 12 Eylül İhtilali'nin yerel basının haber seçimleri üzerindeki etkisi: Hakimiyet gazetesi örneği. S. Gezgin içinde, Türkiye'de yerel basın (s. 111-138). İstanbul: İstanbul Üniversitesi İletişim Fakültesi Yayınları.

Gündüz, U. (2018). Osmanlı'dan günümüze basın ve modernleşme. Ankara: İmge Kitabevi.

Güngör, M. (2008). Çağının önünde koşan bir aydın: İsmayıl Hakkı Baltacıŏlu. Mersin Üniversitesi Eğitim Fakültesi Dergisi, 4(1), 54-64.

Güngör, N. (2011). Illetişim kuramlar ve yaklaşımlar. Ankara: Siyasal Kitabevi.

Güngör, N., \& Tellan, T. (2000). Neo-liberalizmin izlerini dergilerde sürmek. S. İrvan (Dü.), Medya ve kültür içinde (s. 161-192). Ankara: İletişim Dergisi Yayınları.

Gürses, F. (2008). Niyazi Berkes'in Türk kitle iletişim tarihine katkıları. Cumhuriyet Üniversitesi Sosyal Bilimler Dergisi, 32(1), 39-59. 
Kaçmazoğlu, B. (1999). Türk sosyoloji tarihi üzerine araştırmalar öncüleri ve temelleri çerçevesinde yaklaşımlar. İstanbul: Birey Yayıncılık.

Kadıoğlu Ateş, H., \& Akyol, R. (2016). İsmail Hakkı Baltacıoğlu on education. Eurasian Academy of Sciences Eurasian Education\&Literature Journal(5), 16-23.

Keleş, Ç. (1999). Behice Boran'ın iletişim alanına katkıları. Kültür ve İletişim, 2(1), 15-43.

Koloğlu, O. (2006). Osmanlı'dan 21. yüzyıla basın tarihi. İstanbul: Art1 Yayın Dağıtım.

Özçetin, B. (2018). Kitle iletişim kuramları kavramlar, okullar, modeller. İstanbul: İletişim Yayınlar1.

Özman, A. (2006). İsmayıl Hakkı Baltacığlu'nu yeniden okumak: Cinsi Latif'in ölümü ya da erkekliğe methiye. Toplum ve Bilim(107), 190-216.

Öztürk, S. (2006a). Pertev Nail Boratav'1 iletişim bilimi açısından okumak. Akdeniz Üniversitesi İletişim Fakültesi Dergisi(4), 123-161.

Öztürk, S. (2006b). Bir iktisatçının Türk iletişim araştırmalarına katkıları: Sabri Ülgener üzerine notlar. Ekonomik Yaklaşım, 17(58), 89-113.

Öztürk, S. (2006c). Türkiye'nin Düzeni'ni iletişim açısından okumak. Mülkiye, $X X X(253), 29$ 57.

Öztürk, S. (2008). Türkiye'de iletişim düşüncesinin kökenleri. Ankara: Gazi Üniversitesi İletişim Fakültesi Kırkıncı Y1l Kitaplığı.

Öztürk, S. (2009). Türk sosyal bilimcilerini iletişim açısından okumak. Y. Akkaya, Ö. Birler, S. Coşar, \& F. Zapçı içinde, Türkiye'de neoliberalizm, demokrasi ve ulus devlet (s. 273297). İstanbul: Yordam Yayınlar1. doi:978-9944-122-89-4

Özüçetin, Y., \& Mutlu , M. (2016). TBMM müzakerelerinde ortaya koyduğu düşünce ve fikirleri ile eğitimci bir milletvekili: İsmail Hakkı Baltacıŏlu. Uluslararası Avrasya Sosyal Bilimler Dergisi, 7(23), 135-151.

Pekman, Y. (2003). Türk tiyatrosunda çağdaş bir kuramcı: İsmayıl Hakkı Baltacıŏlu. Tiyatro Eleştirmenliği ve Dramaturji Bölümü Dergisi(3), 59-75. 
Tekerek, N. (2005). Tiyatromuzun modern tiyatroyla kesişmesi yolunda gelenekselin önemi ve Baltacıŏlu'ndan bir deneme: "Kafa Tamircisi". Süleyman Demirel Üniversitesi Sosyal Bilimler Enstitüsü Dergisi, 1(1), 157-172.

Timur, T. (2005). Felsefi izlenimler Sartre, Althusser, Foucault, Derrida. Ankara: İmge Kitabevi. doi:975-533-454-8

Tokgöz, O. (2000). Temel gazetecilik (4. Bask1 b.). Ankara: İmge Kitabevi.

Tokgöz, O. (2003). Türkiye'de iletişim eğitimi: Elli yıllık bir geçmişin değerlendirilmesi. Kültür ve İletişim, 6(1), 9-32.

Uzun, R., \& Alemdar, K. (2013). Herkes için gazete-ci-lik. Ankara: Tanyeri Kitap.

Vergili, A. (2014). Bilinmeyen bir yönüyle İsmayıl Hakkı Baltacıŏlu. Sosyoloji Dergisi(29), 407-417.

Young, R. (2017). Rereading the symptomatic reading. N. Nesbitt içinde, The concept in crisis: Reading capital today (s. 35-48). Durham: Duke University Press. doi:978-0-8223$7290-5$ 